\title{
The Hajnal Line and Gene-Culture Coevolution in Northwest Europe
}

\author{
Peter Frost \\ Department of Anthropology, Université Laval, Quebec, Canada \\ Email: peter_frost61z@globetrotter.qc.ca
}

How to cite this paper: Frost, P. (2017). The Hajnal Line and Gene-Culture Coevolution in Northwest Europe. Advances in Anthropology, 7, 154-174.

https://doi.org/10.4236/aa.2017.73011

Received: August 1, 2017

Accepted: August 27, 2017

Published: August 30, 2017

Copyright $\odot 2017$ by author and Scientific Research Publishing Inc. This work is licensed under the Creative Commons Attribution International License (CC BY 4.0).

http://creativecommons.org/licenses/by/4.0/

\begin{abstract}
North and west of a line running from Trieste to St. Petersburg, social relations have long conformed to the Western European Marriage Pattern, i.e., men and women marry relatively late; many people never marry; children usually leave the nuclear family to form new households, and households often have non-kin members. This pattern goes back at least to the thirteenth century and perhaps to prehistoric times. I argue that this environment of weaker kinship caused northwest Europeans to create communities based on shared moral rules, rather than shared kinship. Community members enforced these rules by monitoring not only the behavior of other members but also their own behavior and even their own thoughts. Initially, this new mindset did not have a genetic basis. Individuals acquired it within the bounds of phenotypic plasticity. Over time, however, a genetic basis would have developed through the survival and reproduction of individuals who were better at being socially independent, at obeying universal rules, at monitoring other community members, and at self-monitoring, self-judging, and self-punishing. These psychological adaptations-independent social orientation, universal rule adherence, affective empathy, guilt proneness-are moderately to highly heritable. Although they are complex, they required only minor evolutionary changes to evolve out of mechanisms that were already present but limited to specific behavioral contexts. Affective empathy, for instance, is a species-wide trait but usually confined to relations with close kin, particularly between a mother and her young children. An evolutionary scenario is proposed, and two questions discussed. Are these mental traits too complex to have evolved over a span of 30 to 300 generations? Are they too altruistic to be sustainable?
\end{abstract}

\section{Keywords}

Empathy, Gene-Culture Coevolution, Guilt, Hajnal Line, Northwest Europe, Rule Adherence, Western European Marriage Pattern 


\section{Introduction}

The Hajnal line runs approximately from Trieste to St. Petersburg. To the north and west, social relations have long shown a certain pattern:

- Men and women marry relatively late;

- Many people never marry;

- Children usually leave the nuclear family to form new households;

- Households often have non-kin members (Hajnal, 1965; ICA, 2013; Laslett, 1977).

This is the Western European Marriage Pattern (WEMP). Everyone is single for at least part of adulthood, many stay single their entire lives, and "a significant proportion of households [have] persons not belonging to the immediate family or even to the kin" (Laslett, 1977: p. 13). In short, the individual is less fettered by the bonds of kinship even within the household.

The WEMP was once ascribed to the ravages of the Black Death in the fourteenth century, but this explanation has been refuted by a study of first marriages between 1252 and 1478 in an English community. Even before the Black Death, the average age at first marriage was 24 for the woman and 32 for the man (Hallam, 1985: p. 66).

Earlier periods provide less data to work with. Nonetheless, a high rate of celibacy has been shown at two locations in ninth-century France: the estates of the Abbey of St Germain-des-Prés near Paris, where about $16.3 \%$ of all adults were unmarried, and Villeneuve-Saint-Georges, where the figure was $11.5 \%$. At both locations, households were small and nuclear (Hallam, 1985: p. 56). A ninth-century survey of the Church of St Victor of Marseille shows both men and women marrying in their mid to late twenties (Seccombe, 1992: p. 94). Further back, in the first century, the Roman historian Tacitus wrote about the Germanic tribes, "Late comes love to the young men, and their first manhood is not enfeebled; nor for the girls is there any hot-house forcing; they pass their youth in the same way as the boys" (Tacitus, Germania 20, 1970). Julius Caesar made the same observation:

Those who have remained chaste for the longest time, receive the greatest commendation among their people: they think that by this the growth is promoted, by this the physical powers are increased and the sinews are strengthened. And to have had knowledge of a woman before the twentieth year they reckon among the most disgraceful acts; of which matter there is no concealment, because they bathe promiscuously in the rivers and [only] use skins or small cloaks of deer's hides, a large portion of the body being in consequence naked. (Caesar, De Bello Gallico 6:21, 1915)

The WEMP also includes weaker ties between parents and grown children. This is attested from an early date in English society:

Probably from Anglo-Saxon times-and certainly from the thirteenth century-children had no automatic rights in a parent's property. A child could be disinherited; there is no "family property", nemo est heres viventis 
(no one is the heir of a living person). Maitland documents this in detail, showing that from at least the thirteenth century parents could leave their property to whom they liked-and by gift, sale or will disinherit all their children if they so wished. (Macfarlane, 2012)

Finally, as far back as the earliest written records in northwest Europe, kinship ties were weaker and more focused on the individual, as shown by the practice of tracing ancestry through the male and female lines, with the individual as the starting point. This "ego-focused" system is in contrast to the much more common "unilineal" one of forming descent groups that trace ancestry through one gender, usually the male line.

What is most striking, is that in England, as in much of Europe, this system of reckoning kin has remained practically unchanged since at least the seventh century. [...]

Such a system already predisposes a society towards flexibility, networks and the concept of the individual as more important than the group. Indeed, there are no groups, just ego-centred networks of people. Each individual's kin (except brothers or sisters) is different. This is a central underpinning of an individualistic way of looking at the world. (Macfarlane, 1992: p. 173-174)

By making the individual more important than the group, a weak kinship environment is more conducive to letting the market organize social and economic relations. Markets of one sort or another were present in all areas of early English society.

Recent work on thirteenth century manorial documents has uncovered a very extensive land market from at least the middle of the thirteenth century. There is rapidly accumulating evidence of the buying and selling of pieces of land by non-kin; the idea that land passed down in the family is now increasingly regarded as a fiction. (Macfarlane, 1978: p. 259)

[...] It appears probable that in many areas of England in the period before the Black Death up to half of the adult population were primarily hired laborers. It was not parents and children who formed the basic unit of production, but parents with or without hired labor. This was only made possible by the widespread use of money. The work of Kosminsky and Postan has shown that commutation of labor services for cash was widespread by the middle of the twelfth century. Cash penetrated almost every relationship; selling, mortgaging and lending are apparent in many of the documents. Most objects, from labor to rights in all kinds of property, were marketable and had a price. Production was often for exchange rather than for use. (Macfarlane, 1978: p. 260)

Although markets initially developed the most in the Middle East, they remained localized in space and time, as marketplaces. They failed to spread into other areas of society because people preferred the ties of kinship to the more 
ephemeral ties of commerce. True market economies would arise elsewhere in the world where cultural conditions were more conducive.

The WEMP thus existed for almost a millennium in northwest Europe and perhaps longer. It was a cultural environment with challenges as real as those of the natural environment. People had to adapt to a milieu where kinship ties were weaker and, consequently, less reliable as a means to organize community life and ensure proper behavior.

\section{Coevolution with the WEMP}

Genetic evolution in our species accelerated over a hundred-fold about 10,000 years ago (Cochran \& Harpending, 2009; Hawks et al., 2007; Laland, Odling-Smee, \& Myles, 2010). At that time humans were no longer adapting to new natural environments. They had already spread over most of the earth's surface, from the tropics to the Arctic, and were now adapting to new cultural environments as hunting and gathering gave way to farming - a mode of subsistence that brought not only new food sources but also population growth, sedentary living, and social complexity.

One of these new cultural environments was the WEMP. I will argue that humans adapted to it by developing a more independent social orientation and by creating communities based on shared moral rules, rather than shared kinship. Community members enforced these rules by monitoring not only the behavior of other members but also their own behavior and even their own thoughts. These "moral communities" were made possible by a certain mindset, essentially four interrelated mental traits:

Independent social orientation-independence of the self from others, including stronger motivation toward self-expression, self-esteem, and self-efficacy and emphasis on personal happiness rather than social happiness.

Universal rule adherence-capacity to obey universal and absolute moral rules, i.e., moral universalism and moral absolutism, as opposed to situational morality based on kinship. These rules are enforced by monitoring not only others but also oneself. Rule-breakers may be branded as morally worthless and expelled from the entire moral community, as opposed to being ostracized by close kin.

Affective empathy-capacity to experience the emotional states of other people in order to prevent harm and to provide help if needed. Help is conditional on the other person being judged morally worthy.

Guilt proneness-capacity to self-monitor thoughts and behavior for rule adherence in order to self-judge and, if necessary, to self-punish.

Does this mindset coincide in space and time with the WEMP? This question can be best answered for the last trait, guilt proneness, which has been studied from a cross-cultural perspective. In the anthropological literature, "guilt" is contrasted with "shame," the latter being the primary means in most cultures to enforce correct behavior. Anthropologist Ruth Benedict described the differences 
between guilt cultures and shame cultures:

True shame cultures rely on external sanctions for good behavior, not, as true guilt cultures do, on an internalized conviction of sin. Shame is a reaction to other people's criticism. A man is shamed either by being openly ridiculed and rejected or by fantasying to himself that he has been made ridiculous. In either case, it is a potent sanction. But it requires an audience or at least a man's fantasy of an audience. Guilt does not. In a nation where honor means living up to one's own picture of oneself, a man may suffer from guilt though no man knows of his misdeed and a man's feeling of guilt may actually be relieved by confessing his sin. (Benedict, 1946: p. 223)

In the sociological literature, these two emotional responses are cited to explain differences between Protestant and Catholic Europe. Protestants rely much more on guilt to regulate behavior because their faith is more interiorized and offers less mediation between the believer and God. Also, unlike Catholics, they cannot regularly purge their personal burden of guilt through confession. It thus tends to become pervasive in their lives (Carroll, 1981). For sociologist Max Weber, Protestant Europeans suffer from an "inner loneliness" and "inner isolation of the individual":

[...] In what was for the man of the age of the Reformation the most important thing in life, his eternal salvation, he was forced to follow his path alone to meet a destiny which had been decreed for him from eternity. No one could help him.

[...] this inner isolation of the individual contains, on the one hand, the reason for the entirely negative attitude of Puritanism to all the sensuous and emotional elements in culture and in religion, because they are of no use toward salvation and promote sentimental illusions and idolatrous superstitions. Thus it provides a basis for a fundamental antagonism to sensuous culture of all kinds. On the other hand, it forms one of the roots of that disillusioned and pessimistically inclined individualism which can even today be identified in the national characters and the institutions of the peoples with a Puritan past [...]. (Weber, 1930: p. 104-105)

Yet, even before Protestantism, guilt seems to have been a common emotional response in northwest Europe. The English abbot Aelfric of Eynsham (955-1010) described a kind of shame where the witnesses to a wrongful act are spirits:

He who cannot because of shame confess his faults to one man, then it must shame him before the heaven-dwellers and the earth-dwellers and the hell-dwellers, and the shame for him will be endless. (Bedingfield, 2002: p. 80)

This argument often comes up in Anglo-Saxon literature, forming a "penitential motif":

The motif runs: it is better to be shamed for one's sins before one man (the confessor) in this life than to be shamed before God and before all angels 
and before all men and before all devils at the Last Judgement. (Godden, 1973)

The motif was apparently of native origin:

One particularly interesting fact that emerges is the peculiarly Anglo-Saxon character of the motif. Not only did it circulate widely in Old English writings but the only two Latin works in which I have been able to find it were written by Anglo-Saxons-Alcuin and Boniface. Moreover an important element of the motif, the notion of three hosts present at the Last Judgement, is itself characteristic of Anglo-Saxon writers: the usual representation of the Last Judgement in continental works (as in Alcuin's letter) has the angels and all mankind present, and sometimes the devil as prosecutor, but not the whole host of devils, whereas the concept of the three hosts, as in Boniface's homily, is very common in Old English writings generally. (Godden, 1973)

A pre-Christian reference to guilt may appear in the epic poem The Song of Beowulf where the hero is plagued by "dark thoughts" because he has broken a rule:

That was sorrow to the good man's soul, greatest of griefs to the heart. The wise man thought that, breaking established law, he had bitterly angered God, the Lord everlasting. His breast was troubled within by dark thoughts, as was not his wont. (The Song of Beowulf, 1990)

Northwest European guilt culture may thus predate Protestantism and even Western Christianity, being a pre-existing mindset that was carried over into the new religious context, much like the Christmas tree and other formerly pagan traditions. Later, as the center of Christendom moved west and north, this mindset gained importance within Western Christianity and pushed it more and more toward the idea that everyone inevitably bears a personal burden of guilt. This may be seen in the historical development of the doctrine of original sin, which is absent from Judaism and Islam and was originally identified in Christian tradition with the sin of concupiscence, i.e., ardent, sensual longing. Anselm of Canterbury (1033-1109), an English Catholic, was the first to separate original sin from concupiscence, defining it as "privation of the righteousness that every man ought to possess" (Original sin, 2017). This doctrine assumed its final and most radical form during the Reformation, as seen in the Augsburg Confession of Lutheranism:

It is also taught among us that since the fall of Adam all men who are born according to the course of nature are conceived and born in sin. That is, all men are full of evil lust and inclinations from their mothers' wombs and are unable by nature to have true fear of God and true faith in God. Moreover, this inborn sickness and hereditary sin is truly sin and condemns to the eternal wrath of God all those who are not born again through Baptism and the Holy Spirit. (Original sin, 2017) 


\section{Heritability and Potential for Selection}

A new mindset can become established in a population without changes to the gene pool. Initially, individuals acquire it within the bounds of phenotypic plasticity-by doing the most they can with their existing mindset. Over time, however, a genetic basis will develop through a process of gene-culture coevolution-in this case, through the survival and reproduction of individuals who have been better at being socially independent, at obeying universal rules, at monitoring other community members, and at self-monitoring, self-judging, and self-punishing. Thus, as heritable predispositions strengthen the pattern of adaptation, the new phenotype becomes a new genotype (Laland, Odling-Smee, \& Myles, 2010).

There is moderate to high heritability for all four traits of the northwest European mindset. Each of them has also been identified with specific neural pathways or brain regions.

\subsection{Independent Social Orientation}

This mental trait is influenced by the 5-HTTLPR serotonin transporter gene, whose short allele is more frequent in collectivistic cultures than in individualistic cultures, the latter being the cultures of western and northern Europe (Chiao \& Blizinsky, 2010). The short allele is associated with heightened responsiveness to the social environment. In a study of American toddlers (24 months old), carriers were more likely to imitate the way other people behaved (Schroeder et al., 2016). Social orientation is likewise influenced by the dopamine D4 receptor gene $(D R D 4)$. Some of its alleles are associated with a less independent social orientation and are more frequent in East Asians than in Euro-Americans. Nonetheless, they exert this effect independently of cultural background. When a social orientation test was administered to Euro-Americans and to East Asians from China, Korea, or Japan, the latter were found to be less individualistic than the former, but this difference was limited to carriers of $D R D 4$ variants that increase dopamine signaling. Non-carrier East Asians were just as individualistic as non-carrier Euro-Americans (Kitayama et al., 2014).

\subsection{Universal Rule Adherence}

Heritable predispositions can orient people toward moral universalism, which, among other things, requires one to tell the truth in all social contexts. The alternative-changing one's story to suit one's audience-is called "dishonesty" and seems to be moderately heritable. In a Hawaiian study, the tendency to lie showed the strongest family similarity out of 54 personality traits (Ahern et al., 1982). This genetic influence is supported by a British twin study, which showed that lie scores were more similar for monozygotic twins than for dizygotic twins, heritability being estimated at $48 \%$ (Young et al., 1980). A study of twins and family members similarly estimated broad heritability at $29 \%$ to $42 \%$ (Eaves et al., 1999). In a Swedish twin study, individuals were asked about the acceptability of four dishonest behaviors: claiming sick benefits while healthy $(1.4 \%$ 
thought it totally or fairly acceptable); avoiding payment for public transit (2.8\%); avoiding taxes (9.7\%); and accepting bribes on the job (6.4\%). Heritability was estimated for each response respectively at $42.5 \%, 42.3 \%, 26.3 \%$, and $39.7 \%$. Since honesty correlated only weakly with age, sex, religiosity, preferences for risk and fairness, locus of control, and charitable giving, it did not seem to be a proxy for these other factors (Loewen et al., 2013).

Rule adherence seems to depend on serotonin neural pathways, which are key to behavioral inhibition and executive function. Conversely, reduced biosynthesis of serotonin is associated with a higher level of deceptive behavior (Shen et al., 2016).

Loewen et al. (2013) conclude that studies are needed in other countries because the role and extent of genetic and environmental influences may vary with the cultural context. In many cultures, people behave morally only with close kin. This ethos, called "amoral familialism" in sociology, is a major obstacle to the creation of larger, more complex societies (Banfield, 1958). The adjective "amoral" is misleading here because familialism is a morality in its own right, albeit one that is situational and relativistic rather than universal and absolute. This point should be kept in mind when we see loaded terms like "dishonesty" in the psychological literature. In most cases, dishonesty is not an end in itself but rather one of many means to a common end, i.e., advancement of oneself, one's family, and one's kin by whatever means necessary.

\subsection{Affective Empathy}

Empathy has an estimated heritability of 68\% (Chakrabarti \& Baron-Cohen, 2013). It has two components: cognitive empathy and affective empathy. Some researchers recognize a third, pro-social behavior, but its relationship to the other two seems tangential.

Cognitive empathy (also known as perspective taking) is the capacity to understand how another person is feeling and then predict how different actions will affect that person's emotional state. It can be used for selfish purposes, such as by con artists, telemarketers, and rapists who seek to understand their intended victims in order to entrap them.

Affective empathy (also known as empathic concern) is the capacity not only to understand another person's emotional state but also to experience that state vicariously. It may have initially evolved as a means to bind a mother more closely to her young children, being later extended to other relationships within the group (Decety, 2015). It is perhaps for this reason that affective empathy is stronger in women than in men, whereas cognitive empathy is the same in both sexes (Baron-Cohen \& Wheelwright, 2004; Goerlich-Dobre et al., 2015; Yang et al., 2009). Likewise, young children preferentially show affective empathy toward their mothers (Decety \& Cowell, 2014).

The capacity for affective empathy varies between individuals. Some feel it only for a narrow circle of loved ones; others readily feel it for strangers and even nonhuman pets (Decety \& Cowell, 2014). We half-acknowledge this variation 
when we distinguish between "normal people" and "psychopaths," whose capacity for affective empathy is very low. This normal/abnormal dichotomy makes us lose sight, however, of the continuous variation that exists among those we consider normal (Decety, 2015). Every day, we may meet seemingly normal people whose capacity for affective empathy is much lower than our own.

Just as this capacity varies between individuals, it can also vary between populations because it is more adaptive in some cultural contexts than in others. In most cultures, affective empathy becomes maladaptive the moment it makes no distinction between helping one's kin and helping one's non-kin, especially if the assistance is costly (as opposed to low-cost aid, like giving directions, providing temporary shelter, etc.) and does not flow from an established relationship of reciprocal assistance (such as between longstanding friends).This is not so, however, in northwest European cultures, where kinship ties have long been weaker and where assistance is withheld from "moral outsiders" rather than from non-kin.

Affective empathy results from a sequence of mental events that first produces cognitive empathy. When one observes a person's behavior, mirror neurons respond by firing in tandem, thereby generating a mental model. Copies are sent to other regions of the brain, which decode the nature and purpose of the behavior and predict the sensory consequences for the observed person. An emotional response may occur if this output is fed into one's own emotional state (Carr et al., 2003). Some people will respond emotionally only if the observed person is close kin, and other people only if the observed person is a perceived "moral insider," a perception that requires knowledge of past behavior. In a study with Swiss as the observers and Balkan immigrants as the observed, an emotional response was triggered after only a few positive experiences with the observed person or even with someone similar. The study's authors did not try reversing the ethnic backgrounds of the observers and the observed (Hein et al., 2016).

The relevant brain regions have been identified. Individuals with high cognitive empathy have denser gray matter in the midcingulate cortex and the adjacent dorsomedial prefontal cortex, whereas individuals with high affective empathy have denser gray matter in the insula cortex (Eres et al., 2015). A high capacity for empathy is also associated with enlargement of the amygdala, which controls responses to facial expressions of fear and to other signs of distress (Goerlich-Dobre et al., 2015; Marsh et al., 2014). The left amygdala seems to specialize more in the affective component of empathy and in the related construct of emotional self-awareness (Goerlich-Dobre et al., 2015). Two studies, one American and one English, have found that "conservatives" tend to have a larger right amygdala (Kanai et al., 2011; Schreiber et al., 2013). This has been seen as evidence of "fearfulness" on the political right (Hibbing et al., 2014). One could alternatively say that conservatives are less indifferent to distress in other people and that this political category is a proxy for an ethnic category-individuals of "old stock" northwest European descent.

To test this alternate explanation, we need to measure the capacity for affective empathy in different populations within and outside Europe. A possible 
yardstick is the presence or absence of a deletion variant of the $A D R A 2 b$ gene. Carriers remember emotionally arousing images longer and more vividly, and their amygdala shows more activation when they view such images (Todd \& Anderson, 2009; Todd et al., 2015). We cannot say for sure that "emotional memory" is the same as affective empathy. It seems to be the capacity to deduce an emotional state from visual information (a person's face, a puppy, etc.) and keep it in current emotional experience. It may thus be upstream from affective empathy and closer to cognitive empathy.

Carriers of this variant are more common in some populations than in others. Two studies have shown a higher incidence in Euro-Americans than in African Americans: 31\% versus 12\% (Small \& Liggett, 2001); and 37\% versus 21\% (Belfer et al., 2005). A study with Rwandan participants found an incidence of $21 \%$ (de Quervain et al., 2007). Curiously, carriers were more common in Euro-Canadians (50\%) than in Euro-Americans (31\% - 37\%) (UBC News, 2015, cf. Todd et al., 2015). The reason may be differences in participant recruitment or differences in ethnic mix between the two countries, since people of European descent may have origins on either side of the Hajnal line. Three studies have reported the following incidences in specific European groups: $50 \%$ of Swiss (de Quervain et al., 2007); 56\% of Dutch (Cousijn et al., 2010); 48\% of Israeli Holocaust survivors and $63 \%$ of Israelis who emigrated as children from Europe to British Palestine (Fridman et al., 2012).

Higher incidences have been reported in East Asians: 68\% of Chinese (Zhang et al., 2005); $56 \%$ of one group of Japanese (Suzuki et al., 2003) and $71 \%$ of another (Ishii et al., 2015). Among the Shors, a Turkic people of Siberia, the incidence was $73 \%$. Curiously, male carriers $(79 \%)$ were more common than female carriers (69\%). Male non-carriers might have a higher death rate, since the incidence increased with age (Mulerova et al., 2015).

The picture is still incomplete but the incidence of the $A D R A 2 b$ deletion variant seems to range from $10 \%-20 \%$ of some sub-Saharan African groups to $30 \%-65 \%$ of some European groups and 55\% - 75\% of some East Asian groups. The high values for East Asians suggest that this variant does not measure affective empathy per se but rather empathy in general (both cognitive and affective). East Asians may have followed a somewhat different path of gene-culture coevolution, thereby acquiring a capacity for empathy that is higher but less differentiated into its cognitive and affective components. A study of Chinese university students states that "the cognitive and affective aspects of empathy appear to fuse in Chinese adolescents" (Siu \& Shek, 2005). In a comparative study of young adults in China and the United States, the two groups had similar scores for total empathy (cognitive and affective), but the Americans scored higher on empathic concern and fantasy. "American students may experience more intense feelings of sympathy and concern, and increased ability to imagine experiencing oneself as a character in a work of fiction (e.g., in a book, movie, or play)" (Melissa, 2014: p. 31). A complicating factor in this cross-cultural comparison, as the author notes, is that empathy scores have declined in American college students since 1979. 
Affective empathy ("empathic concern") has dropped the most, followed by cognitive empathy ("perspective taking") (Konrath, O’Brien, \& Hsing, 2010).

It is perhaps significant that the $A D R A 2 b$ deletion variant has a high incidence among the Shors, who were largely hunter-gatherers until recent times. This finding suggests that empathy reached high levels in Eurasia before the advent of farming. The example of the Shors also suggests that non-carriers suffer from a higher death rate, a somewhat surprising finding, given the evidence that carriers have a higher risk of heart disease (Mulerova et al., 2015).

This variant interacts with variants at other genes. People with at least one copy of the short allele of 5-HTTLPR tend to be too sensitive to negative emotional information, but this effect is attenuated by the $A D R A 2 b$ deletion variant, which either keeps one from dwelling too much on a bad experience or helps one to anticipate and prevent repeat experiences (Naudts et al., 2012). As we have seen earlier, the short allele of 5-HTTLPR is less frequent in individualistic cultures than in collectivistic cultures (Chiao \& Blizinsky, 2010). Perhaps the same selection pressure that makes it less frequent also increases the frequency of alleles that limit its phenotypic expression, like the $A D R A 2 B$ deletion variant.

\subsection{Guilt Proneness}

Guilt proneness shows high heritability between families (Cattell et al., 1981). According to a twin study based on a small sample and on parental report, displays of guilt are significantly heritable at 14 months but not at 20 and 24 months (Zahn-Waxler \& Robinson, 1995). Another study found that intensity of childhood trauma is significantly associated with guilt proneness only in carriers of the low-expressing Met allele of $B D N F$ Val66Met. There is a weaker association with the short allele of 5-HTTLPR (Szentágotai-Tătar, 2015). This is our third encounter here with the 5-HTTLPR short allele, which is associated with collectivistic cultures. Such cultures are characterized by strong kinship ties and a tendency to limit affective empathy and guilt proneness to mother-child relations. It may be that childhood trauma disrupts the natural decline in guilt proneness after childhood, causing it to persist into adult life.

The 5-HTTLPR short allele may thus provide another yardstick to measure the capacity for independent social orientation/affective empathy/guilt proneness in different human populations. According to data collated by Chiao and Blizinsky (2010), this allele has a lower incidence in societies of northwest European descent (see Table 1).

The geographic incidence of the 5-HTTLPR short allele is consistent with the Hajnal line and the WEMP. It also suggests that the intensity of selection for the northwest European mindset may be thought of as a series of concentric rings with the highest intensity in the North Sea/Baltic littoral. There is, however, a lack of data from southeast Europe. In fact, Turkey is the only European country that clearly falls outside the WEMP zone and for which we have data. Furthermore, as critics have pointed out, data from multiethnic countries may not be representative; the studies conducted in South Africa, Brazil, Australia, and Argentina used subjects of European descent (Eisenberg \& Hayes, 2011). 
Table 1. Aggregate data on 5-HTTLPR by country (Chiao \& Blizinsky, 2010, Supp. Table $1)$.

\begin{tabular}{|c|c|c|c|}
\hline Country & No. of studies & $\mathrm{N}$ & $\%$ short allele \\
\hline South Africa (of European descent) & 2 & 753 & 27.79 \\
\hline Estonia & 2 & 808 & 34.81 \\
\hline Poland & 4 & 696 & 36.96 \\
\hline Denmark & 1 & 1369 & 40.80 \\
\hline Hungary & 4 & 1067 & 41.71 \\
\hline Finland & 2 & 4269 & 42.45 \\
\hline Slovenia & 1 & 468 & 42.52 \\
\hline Netherlands & 1 & 989 & 42.72 \\
\hline New Zealand & 1 & 847 & 43.03 \\
\hline Germany & 12 & 4105 & 43.03 \\
\hline France & 8 & 2665 & 43.18 \\
\hline Sweden & 3 & 752 & 43.63 \\
\hline Austria & 2 & 416 & 43.65 \\
\hline Russia & 4 & 1370 & 43.91 \\
\hline United Kingdom & 3 & 5888 & 43.98 \\
\hline United States & 14 & 4162 & 44.53 \\
\hline Australia (of European descent) & 4 & 1758 & 45.91 \\
\hline Spain & 8 & 3152 & 46.75 \\
\hline Brazil (of European descent) & 6 & 1747 & 46.96 \\
\hline Italy & 4 & 876 & 48.54 \\
\hline Israel & 8 & 2561 & 49.26 \\
\hline Argentina (of European descent) & 2 & 2012 & 51.04 \\
\hline Mexico & 3 & 380 & 51.96 \\
\hline Turkey & 6 & 1194 & 54.29 \\
\hline India & 3 & 1007 & 58.85 \\
\hline Taiwan & 1 & 192 & 70.57 \\
\hline Singapore & 2 & 629 & 71.24 \\
\hline P.R. of China & 3 & 1896 & 75.20 \\
\hline Korea & 5 & 931 & 79.45 \\
\hline Japan & 5 & 1176 & 80.25 \\
\hline
\end{tabular}

Guilt is closely associated with affective empathy, the two seeming to share much of the same neural wiring. Both are consistently associated with the capacity to recognize facial emotions (Treeby et al., 2016). Both are positively associated with valuing of universalism, benevolence, tradition, and conformity and negatively associated with valuing of power, hedonism, stimulation, and self-direction (Silfver et al., 2008). Guilt cannot exist without affective empathy: 
"People are innately prepared to feel empathic distress in response to the suffering of others, and guilt combines empathic distress with a self-attribution of causal responsibility for the other's suffering" (Baumeister, Stillwell, \& Heatherton, 1994: p. 246).

While guilt may superficially resemble shame, the two show opposing associations with affective empathy:

[...] across several independent studies, shame has been consistently linked to low self-esteem; a tendency to externalize blame; a seething, bitter, resentful kind of anger; an impaired capacity for empathy; and dysfunctional family relationships [...]. Guilt, on the other hand, has been consistently positively related to interpersonal empathy and negatively related to externalization of blame, a detached/unconcerned attitude toward negative interpersonal events, resentment toward others, and a hostile sense of humor, particularly with regard to the unique variance in guilt. (Tangney, Wagner, \& Gramzow, 1992: p. 471)

\section{An Evolutionary Scenario}

To recapitulate, at some point in time, northwest Europeans became less kinship-oriented and more individualistic, and this new cultural environment favored individuals who were more socially independent, more empathic, more guilt-prone, and more adherent to universal moral rules. At first, the new mindset had no genetic basis. Individuals did the best they could with what they had. If, however, some were more inclined toward independent social orientation, universal rule adherence, affective empathy, and guilt proneness, they would do better than others, not only socially but also reproductively. Conversely, the less inclined would do worse. There was thus selection for these traits, and a steady change to the gene pool over time.

Ten generations of selection can significantly change a gene pool (Cochran \& Harpending, 2009: p. 73). Even if the WEMP had not existed before the thirteenth century, it would have exerted a selection pressure on northwest Europeans for some thirty generations. And fragmentary evidence points to its existence as far back as Anglo-Saxon times in England and Roman times on the continent. For earlier periods, historical documents are lacking, and archaeological data can inform us only about more general demographic characteristics.

One might think that the WEMP could not have begun as early as the Mesolithic, i.e., before 7000-6000 BP in northwest Europe. During the Mesolithic, people were hunter-gatherers, a mode of subsistence generally associated with small bands of related individuals. Such a cultural context is not conducive to individualism or to regular interaction with non-kin. It was perhaps for this reason that Inuit hunting bands used shame rather than guilt to ensure correct behavior:

That is, in the past, the individual was expected and encouraged to do what he wanted, and thus had little guilt over most acts. In fact, there was so little 
censure, overtly, that one could do whatever one could get away with. But there was always the shame-concern with what people would think. What guilt existed was very archaic and related to oral incorporation and "bad mother" fears. Taboo-breaking was always a problem but at least one was not "guilty," but simply inappropriate in his acts. (Hippler, 1973)

Things were different, however, among Mesolithic hunter-gatherers who lived along the shores of the North Sea and the Baltic. They were not at all small bands of related individuals.

The societies of the last hunters (and fishers and gatherers) of northern Europe appear to have evolved quickly toward increasing complexity in the period prior to the spread of agriculture. Complexity is defined by greater diversity (more things) and integration (more connections). Advances in technology, settlement, and subsistence are preserved in the archaeological record. During this period technology developed toward greater efficiency in transport, tools, and food procurement. Settlements were generally larger, more enduring, and more differentiated in the Mesolithic than in the preceding Paleolithic. Food procurement was both more specialized and more diversified-specialized in terms of the technology and organization of foraging activities, and diversified in terms of the numbers and kinds of species and habitats exploited. (Price, 1991: p. 229)

From around $8500 \mathrm{BP}$, these hunter-fisher-gatherers began to achieve levels of population density and social complexity like those of farming peoples farther south. They were thus able to halt the advance of farming for two to three thousand years:

After a rapid spread across Central Europe, [...] farming communities came to a halt in the North European Plain, leaving the coastal areas of the North Sea occupied by hunter-gatherers [...].

This could not have been due to ecological conditions. The frontier extends across a uniform geographical area, and the soils of southern Scandinavia are, in many places, light, fertile, and favorable for cultivation [...]. The reason for the delay must be sought in the late Mesolithic communities of the region. Although regional differences exist [...], hunter-gatherers in the southern Baltic region are likely to have had a greater population density than central European foragers [...], larger and more permanent settlements [...], and a complex economic pattern involving specialized extraction camps, seasonal scheduling, and seasonally intensive use of specific resources [...]. (Zvelebil \& Dolukhanov, 1991: pp. 262-263)

These semi-sedentary hunter-fisher-gatherers generally lived from spring to fall in large coastal agglomerations where they fished, sealed, and collected shellfish. They then dispersed inland to small hunting stations (Price, 1991: pp. 220-223). Johansen (2006) has argued for a high degree of mobility: "a number 
of small groups rotating between sites on a seasonal basis within a confined territory, but perhaps periodically aggregating at key localities." Bang-Andersen (1996) states: "In certain areas such as the seaboard of central West Norway, particularly resource-rich marine and terrestrial environments may have made it possible to stay within restricted parts of the region all the year round on a diffuse sedentary basis." Most areas, however, had "a permanent or semi-permanent base camp on the coast, a certain number of extended extraction sites for seasonal hunting, gathering and fishing activities, a larger amount of transitory sites, and an almost indefinite number of special purpose sites or single-activity loci." There was thus seasonal movement: people moving inland in autumn, breaking up into small hunting bands, and regrouping on the coast again in the spring. This back-and-forth movement created a fluid social environment that could be better regulated by guilt than by shame, which works only as long as one still interacts with the witnesses to a shameful act.

Before the Mesolithic, northwest Europe was covered by ice. The WEMP therefore began no earlier than the time of the hunter-fisher-gatherers $(<300$ generations ago) and no later than the thirteenth century ( $>30$ generations ago). Some genetic change can happen even over a span of thirty generations, but the postulated change in mindset may be too much for any time span beginning later than the Pleistocene. This objection is, in fact, central to evolutionary psychology:

It is no more plausible to believe that whole new mental organs could evolve since the Pleistocene-i.e., over historical time-than it is to believe that whole new physical organs such as eyes would evolve over brief spans. It is easily imaginable that such things as the population mean retinal sensitivity might modestly shift over historical time, and similarly minor modifications might have been made in various psychological mechanisms. However, major and intricate changes in innately specified information-processing procedures present in human psychological mechanisms do not seem likely to have taken place over brief spans of historical time.

(Tooby \& Cosmides, 1989: p. 34)

The psychological mechanisms in question are indeed complex. Affective empathy in particular requires being able not only to monitor how other people feel but also to incorporate this emotional state into one's own. Nonetheless, it did not have to arise ex novo. It could have evolved out of a mechanism that was already present but limited to a specific behavioral context, i.e., the relations between a mother and her young children. Guilt proneness may have a similar origin in mother-child relations, i.e., the infantile idea that mother sees all and knows all. We can draw an evolutionary parallel with the capacity to digest milk sugar, which is limited to childhood except in those human groups that have domesticated cattle for milk production (Laland, Odling-Smee, \& Myles, 2010).

Second objection: affective empathy and guilt proneness are too altruistic to be sustainable. They are too easily exploited by individuals who ask for help 
while giving nothing in return. Over time, selection should favor these "free riders" and their offspring at the expense of their empathic, guilt-prone hosts. This scenario is at least partly averted, however, by community members monitoring each other and expelling those who are judged to be "morally worthless." Such behavior monitoring may have evolved in two stages: first, an increase in capacity for cognitive empathy; second, an increase in capacity for affective empathy. Monitoring and expulsion of rule-breakers would have thus evolved in an environment where mutual assistance was much more conditional and much less spontaneous.

If we look at northwest Europeans during the Mesolithic, we see that their annual cycle of fall dispersal and spring reconstitution meets the conditions of the "haystack model," one of the few that can account for evolution of altruistic behavior (Smith, 1964). In this model, empathic, guilt-prone individuals are easily exploited, but the community as a whole benefits from their presence. Communities with many of them will thus expand at the expense of communities with few. As long as the communities regularly split up and reunite, the whole population will show a steady increase in mean capacity for affective empathy and guilt proneness, even though each community will show a decrease during its brief existence.

Guilt proneness and affective empathy may or may not be altruistic, but another behavioral tendency of northwest Europeans clearly is: a relatively large proportion of men and women contribute to the community while remaining celibate and childless. As we have seen, this is a longstanding tendency. How and why did it arise? It might be a side-effect of selection for high parental investment and, thus, for willingness to postpone marriage until one has enough resources for family formation. This selection is achieved at the cost of some people never marrying.

\section{Conclusion}

In North and west of the Hajnal Line, kinship has been a weaker force in social relations since at least the early Middle Ages and perhaps the Mesolithic. Because of this weak kinship environment, northwest Europeans came to view social relations more through the lens of universal moral rules. Such rules were enforced by monitoring not only other community members but also oneself. The new mindset initially developed within the bounds of phenotypic plasticity, but over time it would have been gradually hardwired through selection for independent social orientation, universal rule adherence, affective empathy, and guilt proneness.

This mindset had only limited success at first. While it enabled northwest Europeans to resist the spread of farming from the south and provided an alternate means to build larger and more complex societies, these hunter-fisher-gatherers remained confined to the shores of the North Sea and the Baltic. Even there, farming eventually won out, and their descendants long remained marginal on the world stage politically, economically, and demographically. It was elsewhere, 
principally in the Middle East, that people first reached the benchmarks of cultural development, e.g., urban growth, road building, reading and writing, construction of large polities, etc. Northwest Europeans gained an edge over the rest of humanity only with the rise of the market economy and the success they had in applying this organizing principle to their own societies. They succeeded because their social relations were already less structured by the rival organizing principle, i.e., kinship, and because they were already psychologically adapted to individualism.

In sum, this new mindset freed northwest Europeans from the limitations of kinship and enabled them to organize their societies differently, thus clearing the way for later historical developments, notably the market economy and, later still, the modern State. They thereby met the challenge of creating larger, more complex societies while ensuring orderly social relations.

\section{References}

Ahern, F. M., Johnson, R. C., Wilson, J. R., McClearn, G. E., \& Vandenberg, S. G. (1982). Family Resemblances in Personality. Behavior Genetics, 12, 261-280. https://doi.org/10.1007/BF01067847

Banfield, E. C. (1958). The Moral Basis of a Backward Society. Glencoe, IL: The Free Press.

Bang-Andersen, S. (1996). Coast/Inland Relations in the Mesolithic of Southern Norway. World Archaeology, 27, 427-443. https://doi.org/10.1080/00438243.1996.9980318

Baron-Cohen, S., \& Wheelwright, S. (2004). The Empathy Quotient: An Investigation of Adults with Asperger Syndrome or High Functioning Autism, and Normal Sex Differences. Journal of Autism and Developmental Disorders, 34, 163-175.

https://doi.org/10.1023/B:JADD.0000022607.19833.00

Baumeister, R. F., Stillwell, A. M., \& Heatherton, T. F. (1994). Guilt: An Interpersonal Approach. Psychological Bulletin, 115, 243-267.

https://doi.org/10.1037/0033-2909.115.2.243

Bedingfield, M. D. (2002). The Dramatic Liturgy of Anglo-Saxon England. Suffolk: The Boydell Press.

Belfer, I., Buzas, B., Hipp, H., Phillips, G., Taubman, J., Lorincz, I., Evans, C., Lipsky, R. H., Enoch, M. A., Max, M. B., \& Goldman, D. (2005). Haplotype-Based Analysis of Alpha 2A, 2B, and 2C Adrenergic Receptor Genes Captures Information on Common Functional Loci at Each Gene. Journal of Human Genetics, 50, 12-20.

https://doi.org/10.1007/s10038-004-0211-y

Benedict, R. (1946 [2005]). The Chrysanthemum and the Sword. Patterns of Japanese Culture. First Mariner Books.

Caesar, J. (1915). De Bello Gallico \& Other Commentaries of Caius Julius Caesar. W. A. Macdevitt (Trans.). London: J.M. Dent.

Carr, L., Iacoboni, M., Dubeau, M.-C., Mazziotta, J. C., \& Lenzi, G. L. (2003). Neural Mechanisms of Empathy in Humans: A Relay from Neural Systems for Imitation to Limbic Areas. Proceedings of the National Academy of Sciences (USA), 100, 5497-5502. https://doi.org/10.1073/pnas.0935845100

Carroll, J. (1981). The Role of Guilt in the Formation of Modern Society: England 1350-1800. The British Journal of Sociology, 32, 459-503.

https://doi.org/10.2307/590129 
Cattell, R. B., Klein, T. W., Schuerger, J. M., \& Kameoka, V. (1981). Application of the MAVA Design and the OSES Analysis Method to Determine the Heritability of the Clinical Personality Factors: Guilt Proneness, O; Parmia, H: and Ergic Tension, Q4. Personality Study \& Group Behaviour, 1, 1-22.

Chakrabarti, B., \& Baron-Cohen, S. (2013). Understanding the Genetics of Empathy and the Autistic Spectrum. In S. Baron-Cohen, H. Tager-Flusberg, \& M. Lombardo (Eds.), Understanding Other Minds: Perspectives from Developmental Social Neuroscience. Oxford: Oxford University Press.

https://doi.org/10.1093/acprof:oso/9780199692972.003.0018

Chiao, J. Y., \& Blizinsky, K. D. (2010). Culture-Gene Coevolution of Individualism-Collectivism and the Serotonin Transporter Gene. Proceedings of the Royal Society B, 277, 529-537. https://doi.org/10.1098/rspb.2009.1650

Cochran, G., \& Harpending, H. (2009). The 10,000 Year Explosion. How Civilization Accelerated Human Evolution. New York: Basic Books.

Cousijn, H., Rijpkema, M., Qin, S., van Marle, H. J. F., Franke, B., Herman, E. J., van Wingen, G., \& Fernández, G. (2010). Acute Stress Modulates Genotype Effects on Amygdala Processing in Humans. Proceedings of the National Academy of Sciences U.S.A., 107, 9867-9872. https://doi.org/10.1073/pnas.1003514107

Decety, J. (2015). The Neural Pathways, Development and Functions of Empathy. Current Opinion in Behavioral Sciences, 3, 1-6. https://doi.org/10.1016/j.cobeha.2014.12.001

Decety, J., \& Cowell, J. (2014). The Complex Relation between Morality and Empathy. Trends in Cognitive Sciences, 18, 337-339. https://doi.org/10.1016/j.tics.2014.04.008

de Quervain, D. J.-F., Kolassa, I.-T., Ertl, V., Onyut, P. L., Neuner, F., Elbert, T., \& Papassotiropoulos, A. (2007). A Deletion Variant of the a2b-Adrenoceptor Is Related to Emotional Memory in Europeans and Africans. Nature Neuroscience, 10, 1137-1139. https://doi.org/10.1038/nn1945

Eaves, L., Heath, A., Martin, N., Maes, H., Neale, M. C., Kendler, K., Kirk, K., \& Corey, L. (1999). Comparing the Biological and Cultural Inheritance of Personality and Social Attitudes in the Virginia 30000 Study of Twins and Their Relatives. Twin Research and Human Genetics, 2, 62-80. https://doi.org/10.1375/twin.2.2.62

Eisenberg, D. T. A., \& Hayes, M. G. (2011). Testing the Null Hypothesis: Comments on "Culture-Gene Coevolution of Individualism-Collectivism and the Serotonin Transporter Gene”. Proceedings of the Royal Society B, 278, 329-332. https://doi.org/10.1098/rspb.2010.0714

Eres, R., Decety, J., Louis, W. R., \& Molenberghs, P. (2015). Individual Differences in Local Gray Matter Density Are Associated with Differences in Affective and Cognitive Empathy. NeuroImage, 117, 305-310. https://doi.org/10.1016/j.neuroimage.2015.05.038

Fridman, A., van IJzendoorn, M. H., Sagi-Schwartz, A., \& Bakermans-Kranenburg, M. J. (2012). Genetic Moderation of Cortisol Secretion in Holocaust Survivors: A Pilot Study on the Role of $A D R A 2 B$. International Journal of Behavioral Development, 36, 79. https://doi.org/10.1177/0165025411406859

Godden, M. R. (1973). An Old English Penitential Motif. Anglo-Saxon England, 2, 221-239. https://doi.org/10.1017/S0263675100000442

Goerlich-Dobre, K. S., Lamm, C., Pripfl, J., Habel, U., \& Votinov, M. (2015). The Left Amygdala: A Shared Substrate of Alexithymia and Empathy. NeuroImage, 122, 20-32. https://doi.org/10.1016/j.neuroimage.2015.08.014

Hajnal, J. (1965). European Marriage Patterns in Perspective. In D. V. Glass \& D. E. C. Eversley (Eds.), Population in History. Essays in Historical Demography. Volume I: General and Great Britain (pp. 101-143). New Brunswick (U.S.A.): Aldine Transaction. 
Hallam, H. E. (1985). Age at First Marriage and Age at Death in the Lincolnshire Fenland, 1252-1478. Population Studies, 39, 55-69. https://doi.org/10.1080/0032472031000141276

Hawks, J., Wang, E. T., Cochran, G. M., Harpending, H. C., \& Moyzis, R. K. (2007). Recent Acceleration of Human Adaptive Evolution. Proceedings of the National Academy of Sciences (USA), 104, 20753-20758. https://doi.org/10.1073/pnas.0707650104

Hein, G., Engelmann, J. B., Vollberg, M. C., \& Tobler, P. N. (2016). How Learning Shapes the Empathic Brain. Proceedings of the National Academy of Sciences (USA), 113, 8085. https://doi.org/10.1073/pnas.1514539112

Hibbing, J. R., Smith, K. B., \& Alford, J. R. (2014). Differences in Negativity Bias Underlie Variations in Political Ideology. Behavioral and Brain Sciences, 37, 297-350. https://doi.org/10.1017/S0140525X13001192

Hippler, A. E. (1973). Some Observations on Witchcraft: The Case of the Aivilik Eskimos. Arctic, 26, 198-207. https://doi.org/10.14430/arctic2916

ICA (2013). Research Themes-Marriage Patterns, Institutions for Collective Action. http://www.collective-action.info/_THE_MarriagePatterns_EMP

Ishii, M., Katoh, H., Kurihara, T., \& Shimizu, S. (2015). Catechol-O-Methyl Transferase Gene Polymorphisms in Japanese Patients with Medication Overuse Headaches. JSM Genetics and Genomics, 2, 1-4.

Johansen, K. L. (2006). Settlement and Land Use at the Mesolithic-Neolithic Transition in Southern Scandinavia. Journal of Danish Archaeology, 14, 201-223.

Kanai, R., Feilden, T., Firth, C., \& Rees, G. (2011). Political Orientations Are Correlated with Brain Structure in Young Adults. Current Biology, 21, 677-680. https://doi.org/10.1016/j.cub.2011.03.017

Kitayama, S., King, A., Yoon, C., Tompson, S., Huff, S., \& Liberzon, I. (2014). The Dopamine D4 Receptor Gene (DRD4) Moderates Cultural Difference in Independent versus Interdependent Social Orientation. Psychological Science, 25, 1169-1177. https://doi.org/10.1177/0956797614528338

Konrath, S. H., O”Brien, E. H., \& Hsing, C. (2010). Changes in Dispositional Empathy in American College Students over Time: A Meta-Analysis. Personality and Social Psychology Review, 15, 180-198.

Laland, K. N., Odling-Smee, J., \& Myles, S. (2010). How Culture Shaped the Human Genome: Bringing Genetics and the Human Sciences Together. Nature Reviews Genetics, 11, 137-148. https://doi.org/10.1038/nrg2734

Laslett, P. (1977). Characteristics of the Western Family Considered Over Time. Journal of Family History, 2, 89-115. https://doi.org/10.1177/036319907700200201

Loewen, P. J., Dawes, C. T., Mazar, N., Johannesson, M., Keollinger, P., \& Magnusson, P. K. E. (2013). The Heritability of Moral Standards for Everyday Dishonesty. Journal of Economic Behavior \& Organization, 93, 363-366.

https://doi.org/10.1016/j.jebo.2013.05.001

Macfarlane, A. (1978). The Origins of English Individualism: Some Surprises. Theory and Society, 6, 255-277. https://doi.org/10.1007/BF01681752

Macfarlane, A. (1992). On Individualism. Proceedings of the British Academy, 82, 171-199.

Macfarlane, A. (2012). The Invention of the Modern World. Chapter 8: Family, Friendship and Population. The Fortnightly Review, Spring-Summer Serial.

Marsh, A. A., Stoycos, S. A., Brethel-Haurwitz, K. M., Robinson, P., VanMeter, J. W., \& Cardinale, E. M. (2014). Neural and Cognitive Characteristics of Extraordinary Altruists. Proceedings of the National Academy of Sciences, 111, 15036-15041. 
https://doi.org/10.1073/pnas.1408440111

Melissa, B. (2014). Self-Compassion and Empathy across Cultures: Comparison of Young Adults in China and the United States. International Journal of Research Studies in Psychology, 3, 25-34.

Mulerova, T. A., Yankin, A. Y., Rubtsova, Y. V., Kuzmina, A. A., Orlov, P. S., Tatarnikova, N. P., Maksimov, V. N., Voevoda, M. I., \& Ogarkov, M. Y. (2015). Association of $A D R A 2 B$ Polymorphism with Risk Factors for Cardiovascular Diseases in Native Population of Mountain Shoria. Bulletin of Siberian Medicine, 14, 29-34.

Naudts, K. H., Azevedo, R. T., David, A. S., van Heeringen, K., \& Gibbs, A. A. (2012). Epistasis between 5-HTTLPR and $A D R A 2 B$ Polymorphisms Influences Attentional Bias for Emotional Information in Healthy Volunteers. International Journal of Neuropsychopharmacology, 15, 1027-1036. https://doi.org/10.1017/S1461145711001295

Original sin (2017). Wikipedia. http://en.wikipedia.org/wiki/Original_sin

Price, T. D. (1991). The Mesolithic of Northern Europe. Annual Review of Anthropology, 20, 211-233. https://doi.org/10.1146/annurev.an.20.100191.001235

Schreiber, D., Fonzo, G., Simmons, A. N., Dawes, C. T., Flagan, T., Fowler, J. H., \& Paulus, M. P. (2013). Red Brain, Blue Brain: Evaluative Processes Differ in Democrats and Republicans. PLoS ONE, 8, e52970. https://doi.org/10.1371/journal.pone.0052970

Schroeder, K. B., Asherson, P., Blake, P. R., Fenstermacher, S. K., \& Saudino, K. J. (2016). Variant at Serotonin Transporter Gene Predicts Increased Imitation in Toddlers: Relevance to the Human Capacity for Cumulative Culture. Biology Letters, 12. https://doi.org/10.1098/rsbl.2016.0106

Seccombe, W. (1992). A Millennium of Family Change. Feudalism to Capitalism in Northwestern Europe. London: Verso.

Shen, Q., Teo, M., Winter, E., Hart, E., Chew, S. H., \& Ebstein, R. P. (2016). To Cheat or Not to Cheat: Tryptophan Hydroxylase 2 SNP Variants Contribute to Dishonest Behavior. Frontiers in Behavioral Neuroscience, 10, 82.

https://doi.org/10.3389/fnbeh.2016.00082

Silfver, M., Helkama, K., Lönnqvist, J.-E., \& Verkasalo, M. (2008). The Relation between Value Priorities and Proneness to Guilt, Shame, and Empathy. Motivation and Emotion, 32, 69-80. https://doi.org/10.1007/s11031-008-9084-2

Siu, A. M. H., \& Shek, D. T. L. (2005). Validation of the Interpersonal Reactivity Index in a Chinese Context. Research on Social Work Practice, 15, 118-126. https://doi.org/10.1177/1049731504270384

Small, K. M., \& Liggett, S. B. (2001). Identification and Functional Characterization of a(2)-Adrenoceptor Polymorphisms. Trends in Pharmacological Sciences, 22, 471-477. https://doi.org/10.1016/S0165-6147(00)01758-2

Smith, J. M. (1964). Group Selection and Kin Selection. Nature, 201, 1145-1147. https://doi.org/10.1038/2011145a0

Suzuki, N., Matsunaga, T., Nagasumi, K., Yamamura, T., Shihara, N., Moritani, T., Ue, H., Fukushima, M., Tamon, A., Seino, Y., Tsuda, K., \& Yasuda, K. (2003). a2B-Adrenergic Receptor Deletion Polymorphism Associates with Autonomic Nervous System Activity in Young Healthy Japanese. The Journal of Clinical Endocrinology \& Metabolism, 88, 1184-1187. https://doi.org/10.1210/jc.2002-021190

Szentágotai-Tătar, A., Chiş, A., Vulturar, R., Dobrean, A., Cândea, D. M., \& Miu, A. C. (2015). Shame and Guilt-Proneness in Adolescents: Gene-Environment Interactions. PLoS ONE, 10, e0134716. https://doi.org/10.1371/journal.pone.0134716

Tacitus (1970). Agricola, Germania, Dialogus. Loeb Classical Library. M. Hutton, \& W. Peterson (Trans.). Cambridge (Mass.): Harvard University Press. 
Tangney, J. P., Wagner, P., \& Gramzow, R. (1992). Proneness to Shame, Proneness to Guilt, and Psychopathology. Journal of Abnormal Psychology, 101, 469-478. https://doi.org/10.1037/0021-843X.101.3.469

The Song of Beowulf. (1900). London: J.M. Dent \& Sons.

Todd, R. M., \& Anderson, A. K. (2009). The Neurogenetics of Remembering Emotions past. Proceedings of the National Academy of Sciences U.S.A., 106, 18881-18882. https://doi.org/10.1073/pnas.0910755106

Todd, R. M., Ehlers, M. R., Muller, D. J., Robertson, A., Palombo, D. J., Freeman, N., Levine, B., \& Anderson, A. K. (2015). Neurogenetic Variations in Norepinephrine Availability Enhance Perceptual Vividness. The Journal of Neuroscience, 35, 6506-6516. https://doi.org/10.1523/JNEUROSCI.4489-14.2015

Tooby, J., \& Cosmides, L. (1989). Evolutionary Psychology and the Generation of Culture, Part I. Theoretical Considerations. Ethology and Sociobiology, 10, 29-49. https://doi.org/10.1016/0162-3095(89)90012-5

Treeby, M. S., Prado, C., Rice, S. M., \& Crowe, S. F. (2016). Shame, Guilt, and Facial Emotion Processing: Initial Evidence for a Positive Relationship between Guilt-Proneness and Facial Emotion Recognition Ability. Cognition and Emotion, 30, 1504-1511. https://doi.org/10.1080/02699931.2015.1072497

UBC News (2015). How Your Brain Reacts to Emotional Information Is Influenced by Your Genes.

https://news.ubc.ca/2015/05/06/how-your-brain-reacts-to-emotional-information-is-in fluenced-by-your-genes/

Weber, M. (1930). The Protestant Ethic and the Spirit of Capitalism. New York: Charles Scribner's Sons.

Yang, C.-Y., Decety, J., Lee, S., Chen, C., \& Cheng, Y. (2009). Gender Differences in the $\mathrm{Mu}$ Rhythm during Empathy for Pain: An Electroencephalographic Study. Brain Research, 1251, 176-184. https://doi.org/10.1016/j.brainres.2008.11.062

Young, P. A., Eaves, L. J., \& Eysenck, H. J. (1980). Intergenerational Stability and Change in the Causes of Variation in Personality. Personality and Individual Differences, 1, 35-55. https://doi.org/10.1016/0191-8869(80)90004-5

Zahn-Waxler, C., \& Robinson, J. (1995). Empathy and Guilt: Early Origins of Feelings of Responsibility. In J. P. Tangney, \& K. W. Fisher (Eds.), Self-Conscious Emotions: The Psychology of Shame, Guilt, Embarrassment, and Pride (pp. 143-173). New York: Guilford Press.

Zhang, H., Li, X., Huang, J., Li, Y., Thijs, L., Wang, Z., Lu, X., Cao, K., Xie, S., Staessen, J. A., \& Wang, J.-G. (2005). Cardiovascular and Metabolic Phenotypes in Relation to the $A D R A 2 B$ Insertion/Deletion Polymorphism in a Chinese Population. Journal of Hypertension, 23, 2201-2207. https://doi.org/10.1097/01.hjh.0000189869.48290.91

Zvelebil, M., \& Dolukhanov, P. (1991). The Transition to Farming in Eastern and Northern Europe. Journal of World Prehistory, 5, 233-278.

https://doi.org/10.1007/BF00974991 
Submit or recommend next manuscript to SCIRP and we will provide best service for you:

Accepting pre-submission inquiries through Email, Facebook, LinkedIn, Twitter, etc. A wide selection of journals (inclusive of 9 subjects, more than 200 journals)

Providing 24-hour high-quality service

User-friendly online submission system

Fair and swift peer-review system

Efficient typesetting and proofreading procedure

Display of the result of downloads and visits, as well as the number of cited articles Maximum dissemination of your research work

Submit your manuscript at: http://papersubmission.scirp.org/

Or contact aa@scirp.org 